\title{
ROLA SZKÓL BIZNESU W KONTEKŚCIE DEKLARACJI PRME
}

\section{WSTĘP}

Celem niniejszego tekstu jest zaprezentowanie obecnych w środowisku akademickim wizji, które dotyczą sposobu funkcjonowania uczelni ekonomicznych, zwanych również szkołami czy uniwersytetami biznesu, o czym świadczy np. anglojęzyczna nazwa Uniwersytetu Ekonomicznego w Poznaniu: Poznan University of Economics and Business. Wybrane elementy przedstawionych wizji zostana skonfrontowane $\mathrm{z}$ aksjologicznym wymiarem sześciu zasad odpowiedzialnego kształcenia menedżerów (PRME - Principles for Responsible Management Education) po to, aby możliwe było dokonanie porównania zachodzących tu zgodności bądź rozbieżności. Charakter towarzyszącej temu zabiegowi tezy jest dość skromny, sprowadza się bowiem do przeświadczenia, że zasady PRME są relatywnie trafną odpowiedzią na kształtujące się oczekiwania społeczne środowiska akademickiego i jego otoczenia, w tym niepokoje związane ze zmianą statusu uczelni ekonomicznych we współczesnym społeczeństwie zdominowanym przez wzory myślenia praktycznego i kategorię produktywności. Kwestię tę zauważa m.in. Łukasz Sułkowski, który stwierdza, iż: „Nacisk na większą efektywność nauki powoduje zmniejszenie autonomii kadry oraz uniwersytetu jako instytucji”"

Obecna w tytule artykułu kategoria roli, nawiązująca do słownika socjologii, została zastosowana w pełni świadomie: desygnatami tego pojęcia sa definiowane społecznie sposoby rozumienia typu obecności i postaci pożądanych rezultatów funkcjonowania uczelni ekonomicznych w obszarze kształcenia, badań naukowych oraz rodzaju powiązań odnośnej instytucji ze sfera społeczno-ekonomiczną. Nie chodzi zatem o dostępne konceptualizacje modelu wyższej edukacji ekonomicznej, w ramach których wskazuje się i wyjaśnia kulturowe funkcje instytucji uniwersytetów ekonomicznych, a więc o teoretyczny ich opis, z którego nie wynikają bezpośrednie korzyści praktyczne lecz o uniwersytetów tych współczesne wyobrażenia.

${ }^{1}$ Ł. Sułkowski, Od uniwersytetu humboldtowskiego do uniwersytetu przedsiębiorczego, „Niezbędnik Akademicki” 2017, nr 2 [online], <http://niezbednikakademicki.pwn.pl/> [dostęp: 5.10.2017], s. 8. 


\section{UNIWERSYTET-PRZEDSIĘBIORSTWO CZY UNIWERSYTET PRZEDSIĘBIORCZY}

Rozstrzygnięcie, na czym powinna polegać społeczna rola uniwersytetów ekonomicznych czy szkół biznesu, wzbudza liczne kontrowersje i jednym z powodów jest odmienność przyjmowanych wartościowań odnośnie do tych instytucji ${ }^{2}$. Wartościowania te są również udziałem wypowiedzi zawartych w pracy Ilony Zakowicz podejmującej problematykę współczesnych wizji uniwersytetu w nawiązaniu i w zasadzie w konfrontacji z klasyczną XIX-wieczną koncepcja Wilhelma von Humboldta, która ukształtowała kwestionowany dziś model uniwersytetu ${ }^{3}$. Wyrażając wątpliwości wobec dokonujących się $\mathrm{w}$ tym względzie przemian, Zakowicz korzysta $\mathrm{w}$ tekście z prac innych autorów, którzy twierdzą m.in.: „że na nieznaną dotychczas w historii skalę nauka i wiedza zostały wprzęgnięte w służbę wielkiej polityki i wielkiego kapitału. Trendy te nakazuja traktować wiedzę jako towar, który powinien być wysokiej jakości i użyteczny społecznie oraz dobrze się sprzedać” ${ }^{4}$. Rozpoznajac owe przemiany jako niekorzystne, Zakowicz przywołuje dwie wyraźnie zaznaczające się wizje uniwersytetu zaczerpnięte z kolei z pracy Marii Czerepaniak-Walczak ${ }^{5}$, tj. koncepcję „uniwersytetu-przedsiębiorstwa” oraz „uniwersytetu przedsiębiorczego” (drugie pojęcie zostało spopularyzowane i rozpowszechnione przez Burtona Clarka w pracy Creating Entrepreneurial Universities. Organizational Pathways of Transformation, 19986). W opisie idei „uniwersytetu przedsiębiorstwa” Zakowicz stwierdza, że „wraz ze zmianami w sferze ładu społecznego następuja też zmiany w przesłankach i funkcjonowaniu uniwersytetu, który z instytucji naukowej i kulturotwórczej wyraźnie przemienia się w przedsiębiorstwo"7. Odnosząc się nieprzychylnie do postrzegania uniwersytetu na wzór przedsiębiorstwa, Czerepaniak-Walczak wskazuje na perswazyjny wymiar terminologii, której używa się, pisząc o uniwersytetach: „usługi edukacyjne”, ,produkcja wiedzy”, „klient”, „kapitał intelektualny”, „zarządzanie wiedzą”. To zaś, że pracodawca oczekuje od uniwersytetu wyspecjalizowanego kapitału ludzkiego, przyczynia się do komercjalizacji edukacji i szkolnictwa wyższego, która „generuje kulturę konformizmu, stojącą w wyraźnej sprzeczności wobec tradycyjnej

${ }^{2}$ B. Pogonowska, Edukacja etyczna oraz odpowiedzialne kształcenie menedżerów - krytyczna samoocena, w: W. Gasparski, B. Rok (red.), Ku obywatelskiej rzeczpospolitej gospodarczej, Warszawa 2010, s. 199-206.

${ }^{3}$ I. Zakowicz, Idea uniwersytetu Wilhelma von Humboldta - kontynuacja czy zmierzch? „Ogrody Nauk i Sztuk” 2012, nr 2, s. 62-74 [online], <https://www.google.pl/search?q=model+uni wersytetu+w+ujęciu.+Aleksandra+von+Humboldta\&oq> [dostęp: 23.07.2017].

${ }^{4}$ Za: ibidem, s. 71; K. Wrońska, Pytanie o wolność w przestrzeni uniwersytetu. Obszary i granice autonomii oraz swobód akademickich - między przywilejem a powinnościa, w: D. Pauluk (red.), Student na wspótczesnym uniwersytecie. Ideały i codzienność, Kraków 2010, s. 102.

${ }^{5}$ M. Czerepaniak-Walczak, Uniwersytet - instytucja naukowo-edukacyjna, czy przedsiębiorstwo? Szkoła wyższa w procesie zmiany, w: J. Piekarski, D. Urbaniak-Zając (red.), Innowacje w edukacji akademickiej. Szkolnictwo wyższe w procesie zmian, Łódź 2010, s. 55.

${ }^{6}$ Za: Ł. Sułkowski, op. cit., s. 10.

${ }^{7}$ Za: I. Zakowicz, op. cit., s. 70-72; M. Czerepniak-Walczak, op. cit., s. 55. 
roli uniwersytetu jako źródła społecznego krytycyzmu”8. Koncepcja druga, czyli „uniwersytet przedsiębiorczy” w rozumieniu Czerepaniak-Walczak ${ }^{9}$, skłania się wprawdzie ku znaczeniu oddziaływania przemian społecznych na postrzeganie roli uczelni, ale nie rezygnuje z własności, o których sądzi się, że są w stanie zachować tożsamość uniwersytetu w sensie klasycznej wizji Humboldta. Wizja ta zasadza się na „racjonalnym (twórczym, efektywnym) zarządzaniu kapitałem społecznym i intelektualnym przez procesy i działania specyficzne dla uczelni, tzn: badania, kształcenie i kulturotwórcze relacje ze środowiskiem. Uniwersytet przedsiębiorczy, to także, a może przede wszystkim miejsce intersubiektywnych relacji nacechowanych *świadomością (wiem, zdaję sobie sprawę, że...), *intencjonalnością (chcę, zamierzam) wyborów, *odpowiedzialnością za nie"10.

W ramach prezentowania dyskusji dotyczącej współczesnych przemian uniwersytetu warto zwrócić uwagę na spostrzeżenia Sułkowskiego, który odnosząc się pozytywnie do sytuacji, w której „Uniwersytet Posthumboldtowski, obok misji w postaci badań naukowych i kształcenia wyższego, zyskuje "trzecią misję" w postaci kontaktów z otoczeniem społeczno-gospodarczym oraz edukacji obywatelskiej"11, zauważa również zagrożenia w postaci procesu marginalizowania tradycyjnych wartości uniwersyteckich typu emancypacja jednostki, poszerzanie horyzontów intelektualnych, rozwijanie krytycyzmu i tworzenie wspólnego dobra, czyli nauki - na rzecz wartości, która jest pozycja konkurencyjna uniwersytetu przedsiębiorczego ${ }^{12}$.

Zakres i treść toczonych dyskusji prezentują w interesujacy sposób rozważania Krzysztofa B. Matusiaka i Małgorzaty Matusiak ${ }^{13}$, którzy podejmujacc zagadnienie współczesnych modeli uniwersytetu, koncentrują się na kwestii „przedsiębiorczości środowiska naukowego” i wskazują m.in. na kulturowe uwarunkowania sposobu pojmowania tego zjawiska. Na przykład w kulturze anglosaskiej pojęcie „uniwersytetu przedsiębiorczego” jest utożsamiane najczęściej „z procesem powstawania w uczelniach tzw. spin-off i spin-out (które są zakładane i prowadzone przez pracowników naukowych i studentów) oraz z przedsiębiorczością uczelni - wszystkich tych sytuacji, w których uczelnia występuje jako oferent określonego typu know-how i chce je sprzedać na czysto rynkowych zasadach ${ }^{14}$. Nie opowiadając się do końca za wartościami, które wspierają tak pojmowana przedsiębiorczość, autorzy wskazuja na już rozpowszechnione w uczelniach w Polsce rozumienie idei „uniwersytetu przedsiębiorczego" w kategoriach działań, które polegają na promowaniu przedsiębiorczości studentów w procesie kształcenia, edukacji tej przedsiębiorczości oraz postrzeganiu szkoły wyższej jako instytucji, która może i powinna być dobrze

${ }^{8}$ Za: I. Zakowicz, op. cit., s. 70; W. Stróżewski, O idei uniwersytetu, w: idem, W kręgu wartości, Kraków 1992, s. 8.

${ }^{9}$ Ibidem, s. 55.

${ }^{10}$ Ibidem, s. 58.

${ }^{11}$ Ł. Sułkowski, op. cit., s. 10.

${ }^{12}$ Ibidem, s. 8.

${ }^{13}$ K.B. Matusiaka, M. Matusiak, Pojęcie i ekonomiczne znaczenie przedsiębiorczości akademickiej, „Zeszyty Naukowe Uniwersytetu Szczecińskiego. Ekonomiczne Problemy Usług” 2007, nr 8(453), s. 155-165 [online], <http://www.wzieu.pl/zn/653/spis_653.pdf> [dostęp: 10.10.2017].

${ }^{14}$ Ibidem, s. 158. 
zarządzana ${ }^{15}$. Natomiast watpliwości budzi wskazanie przedsiębiorstwa za wzór owego zarządzania - byłby to symptom zgody na „korporacyjną" uczelnię oraz „korporacyjną” naukę.

Z pewnością spośród przywołanych koncepcji wizja „uniwersytetu przedsiębiorczego" - zwłaszcza w ujęciu Zakowicz oraz Sułkowskiego - jest nieporównanie bliższa ideom prezentowanej poniżej deklaracji PRME niż koncepcja „uniwersytetu-przedsiębiorstwa”.

\section{PRME: PRINCIPLES FOR RESPONSIBLE MANAGEMENT EDUCATION}

Zasady społecznie odpowiedzialnego kształcenia menedżerów (PRME) zostały przyjęte w Genewie w 2007 r. z inicjatywy Organizacji Narodów Zjednoczonych oraz władz i przedstawicieli sześćdziesięciu głównych szkół biznesu i instytucji akademickich [PRMEa]. Obecnie PRME jest „światowym forum odpowiedzialnego kształcenia menedżerów [...], które uzyskało rekomendację ze strony organizacji Global Compact (http://ungc.org.pl/). Program po raz pierwszy został ogłoszony na szczycie liderów Global Compact w 2007 r." [PRMEb]. Celem PRME jest „inspirowanie i zachęcanie do odpowiedzialnego zarządzania edukacja, badaniami naukowymi i globalnym myśleniem poprzez zastosowanie sześciu zasad, do których przestrzegania zobowiązuja się sygnatariusze tej deklaracji: „Zasada 1 - Cel: Będziemy rozwijać zdolności studentów, aby mogli być przyszłymi twórcami zrównoważonych wartości dla biznesu i ogółu społeczeństwa i by mogli pracować na rzecz inkluzywnej, globalnej gospodarki. Zas ada 2 - Wartości: Włączymy w nasza działalność akademicką i programy nauczania zasady globalnej odpowiedzialności społecznej, przedstawiane przez międzynarodowe inicjatywy, takie jak United Nations Global Compact. Zasada 3 - Metoda: Stworzymy edukacyjne ramy, materiały, procesy oraz środowiska, które umożliwią efektywne przyswajanie wiedzy i doświadczeń odpowiedzialnego przewodnictwa. Za sa da 4 - Bad a ni a: Zaangażujemy się w pojęciowe i empiryczne badania, które rozwiną nasze rozumienie roli, dynamiki i wpływu korporacji na tworzenie zrównoważonych wartości społecznych, środowiskowych i ekonomicznych. Za sa da 5 - Partnerstwo: Będziemy współdziałać z kierownictwem korporacji i biznesu, aby poszerzyć naszą wiedzę na temat wyzwań, które staja przed nimi na drodze do podjęcia odpowiedzialności społecznej i środowiskowej i aby zbadać wspólnie skuteczne sposoby podejścia do tych wyzwań. Zasada 6 - Dialog: Będziemy ułatwiać i podtrzymywać dialog i debatę na temat rozstrzygających kwestii, związanych z globalną odpowiedzialnościa społeczna i zrównoważonym rozwojem, pomiędzy wychowawcami, studentami, biznesem, rządami, konsumentami, mediami, organizacjami pozarządowymi i innymi interesariuszami. Celem tych zasad jest ustanowienie procesu ciagłego udoskonalania się instytucji kształcących menadżerów, aby stworzyć nowe

${ }^{15}$ Ibidem. 
pokolenie liderów biznesu, zdolnych zmierzyć się z całą złożonością wyzwań, przed którymi stają firmy i społeczeństwo w XXI wieku” [PRMEb].

Literalne przedstawienie Zasad PRME uznano za niezbędne ze względu na zamiar niniejszego tekstu. Ponadto można sądzić, że sama idea nie jest jeszcze w środowisku uczelni w Polsce zbyt dobrze znana, skoro sygnatariuszami tej deklaracji sa - jak dotąd - jedynie cztery instytucje/jednostki akademickie: Szkoła Główna Handlowa, Akademia Leona Koźmińskiego, Wydział Zarzązania Uniwersytetu Warszawskiego oraz Uniwersytet Ekonomiczny w Poznaniu. Jak wiadomo, instytucje akademickie, które przyłączyły się do tej inicjatywy, są zobowiązane do składania corocznych raportów z postępów $\mathrm{w}$ wywiązywaniu się $\mathrm{z}$ realizacji odnośnych sześciu zasad. Zawarte w raportach informacje stanowią każdorazowo świadectwo aktualnie przyjmowanych przez daną Uczelnię interpretacji oraz wykładni wartości-sensów postulowanych $\mathrm{w}$ ramach deklaracji PRME.

\section{REFLEKSJA HUMANISTYCZNA W UNIWERSYTETACH EKONOMICZNYCH}

Zabierając głos w dyskusji na temat kształcenia ekonomicznego w szkołach wyższych, Ewa Chmielecka stwierdza, że zgodnie z ideą zrównoważonego rozwoju: „Jakość ludzkiego życia, a nie ilość konsumowanych produktów miałaby być wymiarem rozwoju. Oznaczałoby to włączenie do oceny rozwoju - obok wskaźników ekonomicznych - wartości per se. [...] Samo jednakże włączenie wartości w ocenę rozwoju oznacza, że kształcenie wszystkich profesjonałów, w tym techników i menedżerów, powinno je obejmować"16. Ponieważ rozwój technologiczny jest ponadnarodowy, a zatem uniwersalny w sensie przepływu idei czy rozwiązań technicznych i organizacyjnych, to owe wartości również powinny być uniwersalne. Odwołując się do wprowadzonej przez Arystotelesa triady pojęć empeiria, techne i sofia i współczesnego podziału na kategorie informacji, wiedzy i mądrości, cytowana autorka wskazuje na umiejscowienie pojęcia informacji w perspektywie myślenia technokratycznego i menedżerskiego. Odnośna perspektywa skoncentrowana jest na poszukaniu odpowiedzi na pytania typu: „co?”, ”gdzie?”, jakie?”, „co zrobić, aby?”, i dla której pytanie: „dlaczego?” nie jest ważne. To ostatnie wraz z pytaniami: „po co?”, „w jakim celu?”, „czy to cel dobry, czy słuszny?”, jest podstawą myślenia humanistycznego, które także i dziś z podejrzliwością przypatruje się kategoriom sprawności technologicznej i ekonomicznej uznawanych za oczywiste w ich wartościującej nadrzędności, i przy tym postrzeganych jako niezależne od wszelkich wartości. Dopiero połączenie wiedzy i wartości tworzy mądrość, w konsekwencji także społeczeństwo mądrości, które dobrze (tj. na podstawie refleksji), dobiera i wartościuje swoje cele. Zdaniem Chmieleckiej tej podejrzliwości brakuje jednak w procesie kształ-

${ }^{16}$ E. Chmielecka, Informacja, wiedza, madrość. Co społeczeństwo wiedzy cenić powinno?, konferencja: Dobre obyczaje w ksztatceniu akademickim, 2004 [online], <https://www.e-sgh.pl/ lms/content/9160101/zasoby_dod.pdf> [dostęp: 1.07.2017], s. 7. 
cenia w uczelniach wyższych, które przecież - zgodnie z wymogami Deklaracji bolońskiej z 1999 r. - powinno obejmować kształtowanie wiedzy, umiejętności praktycznych oraz postaw (kompetencji społecznych) studentów i studentek.

Chodzi tu niewątpliwie o potrzebę rozpowszechniania wśród młodego pokolenia trwałych postaw o postaci wartościujacej refleksji „nakładanej” na działania celowo-racjonalne (praktycznie uchwytne), takich jak np. praktyki zmierzające do osiaggania zysku przez przedsiębiorstwo. Wydarzenia współczesnego świata, warunkowane przez procesy globalizacji kulturowej, w tym gospodarczej, ruchy fundamentalistyczne oraz terroryzm i równolegle - przez działania społeczeństwa obywatelskiego ,wymagaja od współczesnych warstw oświeconych kwalifikacji znacznie przekraczających czystą wiedzę i umiejętności profesjonalne. Konieczne jest stawianie pytania »Ku czemu zmierza współczesny świat?"'17. Wydarzenia, których doświadczamy, wymagaja uczestnictwa, zaangażowania w sprawy świata, odpowiedzialności i refleksji. „Widać, że idzie tu raczej o rozwój tego, co nazywam społeczeństwem mądrości, niż społeczeństwem czystej wiedzy"18.

Wskazując na sposoby kształtowania społeczeństwa mądrości przez społeczność szkół wyższych Chmielecka wymienia m.in.: relację uczeń-mistrz, jakkolwiek trudną do osiagnięcia w systemie masowej edukacji, akty zabierania głosu przez nauczycieli akademickich bądź ich przedstawicieli w kwestiach ważnych, które to akty sprzyjają budowaniu społecznej wrażliwości, funkcjonowanie uczelni w środowisku międzynarodowym, które uczy otwartości i poszanowania różnorodności kulturowej, podmiotowe traktowanie studentów, które zachęci młodych ludzi do uczestnictwa i zaangażowania w działania i cele niepowiązane z bezpośrednią jednostkową korzyścia, lecz służące rozwiązywaniu lokalnych problemów społecznych.

Eksponując klasyczną edukację humanistyczną w duchu refleksji nad fundamentalnymi kwestiami człowieczeństwa i uznając ją za niezbędny komponent programu studiów wyższych, zwłaszcza biznesowych, Chmielecka wskazuje na kształtowanie przez tę edukację wrażliwości na wartości autoteliczne i troski o sprawy publiczne oraz wpajanie przekonania, że absolwent szkoły wyższej przechodzi do grupy społecznej o szczególnych obowiązkach wzorotwórczych, takich jak: postawy obywatelskie, dbałość o kulturę wysoka, racjonalne myślenie przede wszystkim w kategoriach szeroko pojmowanej odpowiedzialności społecznej, w tym globalnej ${ }^{19}$. Brak tak pojmowanej edukacji bądź sprowadzenie jej do instrumentalnego kształcenia (np. w ramach przedmiotu etyki biznesu realizowanej pod hasłem ethics pays) jest w istocie ukrytą indoktrynacją polegająca na utrwalaniu studentów w przekonaniu, że wartości moralne nie sa ważne i że do powodzenia w życiu wystarcza jedynie wartości profesjonalne, praktyczne, narzędziowe. Warto podkreślić, że kwestionowane przez Chmielecką przekonanie jest zdaniem wartościującym silnie zakorzenionym $\mathrm{w}$ znanych nurtach scjentystycznych, w tym technokratycznych i menedżerskich.

\footnotetext{
17 Ibidem, s. 11.

18 Ibidem, s. 12.

19 Ibidem, s. 13.
} 
Próbę interpretacji tekstu Chmieleckiej z perspektywy zasad utworzonej kilka lat później międzynarodowej inicjatywy PRME można rozpoczać od stwierdzenia, że pomiędzy oboma tekstami nie zachodzą żadne merytoryczne czy też aksjologiczne rozbieżności. Eksponowany w tekście filozofki wątek potrzeby tworzenia społeczeństwa mądrości w obliczu wyzwań współczesności znajduje odzwierciedlenie w idei społeczeństwa opartego na wartościach zrównoważonego rozwoju oraz globalnej odpowiedzialności społecznej i środowiskowej (zasada 2) i zarazem stanowi odpowiedź na zadane pytanie „Ku czemu zmierza współczesny świat?” (zasada 1). PRME odwołuje się do wartości ponadnarodowych (uniwersalnych), a postulat Chmieleckiej związany z potrzebą usensowienia świata wyraża się w zamiarze kształtowania inkluzywnej globalnej gospodarki (zasada 1). W Deklaracji PRME wskazane sa także szczególne wzorotwórcze obowiązki absolwentów uczelni ekonomicznych jako przyszłych twórców biznesu i społeczeństwa (zasada 1 i 3). Natomiast krytykowane przez Chmielecką jako niewystarczające profesjonalne (narzędziowe) umiejętności stały się w myśl PRME podstawą prowadzenia debaty i dialogu $\mathrm{z}$ uniwersytetu z jego wewnętrznymi i zewnętrznymi interesariuszami w imię kształtowania globalnej odpowiedzialności społecznej, debaty odpowiednio tj. aksjologicznie - ukierunkowanej.

Pojawia się w tym momencie pytanie, jakie intelektualne bądź/i praktyczne korzyści wynikają z analiz konfrontowania pracy filozofki i zasad PRME. Uznając, że wypowiedź Chmieleckiej jest reprezentatywna dla opinii przynajmniej części środowiska akademickiego nie tylko uczelni ekonomicznych w Polsce, można by stwierdzić, że decyzja o przystapieniu do inicjatywy PRME wspomnianych czterech instytucji/jednostek była w jakiejśs mierze podyktowana obecnością w debacie publicznej przekonań wskazujących na kształtowanie się wewnątrz i poza środowiskiem akademickim określonych oczekiwań społecznych - oczekiwań, które wyrażają konieczność pewnego zinstytucjonalizowania refleksji dotyczącej miejsca i roli uczelni ekonomicznych we współczesnym świecie. Dodajmy, że wykorzystanie przez inicjatorów PRME idei społecznej odpowiedzialności biznesu było zabiegiem z jednej strony efektywnym praktycznie, albowiem wyeksponowano oczywistość powiązań uczelni ze sferą biznesu, z drugiej zaś - aksjologicznym rozstrzygnięciem odnośnie do powierzenia uniwersytetom misji kształcenia takich liderów, którzy są zdolni „zmierzyć się z całą złożonością wyzwań, przed którymi stają firmy i społeczeństwo w XXI wieku” [PRMEb].

\section{KRYTYCZNA DIAGNOZA STANU SZKÓŁ BIZNESU}

Podczas internetowej dyskusji w 2008 r. zorganizowanej przez czasopismo „Ephemera: Theory \& Politics in Organization”, w której wzięło udział czterech badaczy wywodzących się z nurtów krytyczno-emancypacyjnych: Stefano Harney (antropologia i socjologia, University of Leicester Management School), Martin Parker (socjologia, kultura i organizacje, Warwick Business School) oraz Tony Tinker (krytyczne studia nad rachunkowościa, City Uni- 
versity of New York), zarysowano wielowątkową krytyczną diagnozę współczesnej sytuacji oraz wskazano postaci pożądanych kierunków przekształceń uczelni ekonomicznych i szkół biznesu. Wypowiedzi akademików były moderowane i komentowane przez badacza z University of Leicester i przedstawiciela czasopisma „Ephemera” - Stephena Dunne (teoria społeczna, konsumpcja).

Na wstępie dyskusji pojawiło się twierdzenie, że współczesne szkoły biznesu to swoiste „domy towarowe”, a dobrowolnie utowarowieni uczeni prowadzacy badania i kształcący studentów tworzą nowy niewzruszony kapitał, dlatego że kierują się konformizmem wobec siebie i biznesu oraz traktują uczelnie po prostu jako miejsce pracy. Dawniej uczelnie służyły reprodukcji elit, natomiast obecnie zajmuja się reprodukcją kapitału - stąd trafne jest określenie tej sytuacji mianem „kapitalizmu akademickiego” ${ }^{20}$. Nauczanie i badania sa oceniane przede wszystkim ze względu na ich użyteczność i sprzedaż. Doszło do odrażającej profesjonalizacji pracy akademickiej, która polega na wyłonieniu się grupy ludzi, którzy znają impact factor czasopism, w których zamierzają publikować, i są skłonni napisać cokolwiek z kimś, kto jest osobą uznana i kogo zwa profesorem ${ }^{21}$. W prekapitalistycznej przeszłości wielość i relatywne zróżnicowanie dyscyplin i kierunków akademickich mogły być uznawane za pewien rodzaj świadectwa, że interesy całego społecznego kontekstu sa przez uniwersytety reprezentowane czy podzielane. Natomiast dziś to szkoły biznesu i tzw. Big Science są czołowymi graczami, a większość zatrudnionych uczonych koncentruje się przede wszystkim na własnej karierze, stabilności pracy, dochodach i statusie społecznym ${ }^{22}$.

Kolejny temat dyskusji to status Critical Management Studies (CMS): stwierdzono, że wpływ tego nurtu nie wykracza poza uniwersytety i że łatwo być krytycznym, przebywając w pokoju seminaryjnym i pracując ze studentami. W podobnej sytuacji sa też inne nauki stosowane, np. prawo, pedagogika, praca socjalna czy architektura, jakkolwiek wszystkie te dyscypliny maja we własnej historii momenty o „krytycznym” wydźwięku. CMS jest dziś jedynie etykietą taktycznie użyteczną dla niektórych badaczy, a poza tym dziś nie wystarczy już tylko pisać o tożsamości czy dyskursie, aby być krytycznym trzeba być zaangażowanym w sprawy lokalności oraz problemy redystrybucji bogactwa. Żadna epistemologia - i CMS również - nie gwarantuje bowiem pojawienia się określonych efektów politycznych ${ }^{23}$.

Warto podkreślić, że podjęta przez dyskutujących uczonych problematyka upolitycznienia badań naukowych w ekonomii i naukach o zarządzaniu dotyczyła kwestii, w jakim stopniu dyscypliny te sa powiązane ze sprawami publicznymi. Wskazali na wydarzenia w USA dotyczące publicznego zaangażowania się środowiska nauk prawnych pod nazwą Critical Legal Studies (CLS) oraz nauk społecznych w postaci Critical Race Theory, traktujac te przykłady jako uzasadnienie przeświadczenia, że tworzona w murach uniwersytetu idea może funkcjonować w ważny politycznie sposób, tj. dostarczać legitymizacji

\footnotetext{
20 Ibidem, s. 273.

21 Ibidem, s. 274.

22 Ibidem, s. 275.

23 Ibidem, s. 276.
} 
działaniom organizacji pozarządowych na całym świecie. Z kolei CMS może wykorzystywać umiejętności właściwe dla organizacji pozarządowych w celu wykrywania korupcji oraz politycznie uwikłanych przestępstw; CMS jest intelektualnym ruchem z własną otwartą przestrzenią, którą tworzą publikacje i konferencje, jest w stanie przenikać do różnych środowisk zawodowych. Niewątpliwie CMS jest odpowiednią przestrzenia dla tych badaczy i studentów, którzy sądza, że coś złego dzieje się ze światem: there is something wrong with the world ${ }^{24}$. Dlatego CMS powinno stać się poczatkiem porozumienia między uczelniami i tworzenia się ruchów społecznych w uczelniach, jak było w przypadku wspomnianego ruchu CLS w latach osiemdziesiątych i dziewięćdziesiątych ubiegłego wieku, ruchu, który w uczelniach zdominowanych przez poglądy prawicowe działał na rzecz zniesienia kary śmierci. Bez takich porozumień nie uda się umieścić w programach studiów biznesowych CSR, etyki, krytycznie uprawianych nauk o zarządzaniu i rachunkowości ${ }^{25}$. Potrzebny jest intelektualny ruch, zwłaszcza w czasie gdy większość badaczy z obszaru biznesu i zarządzania to hipokryci, których kłamstwa są tak często powtarzane, że przenikają do wiedzy potocznej. Niestety dla większości akademików nie są ważne dyskusje dotyczące tego, jakie powinny być programy studiów, które teksty powinny być studiowane i wobec kogo uczelnie winny być odpowiedzialne. Mimo wszystko można jednak wierzyć w to, że w szkołach biznesu jest „coś” więcej niż tylko biznes czy zarządzanie - nie nazywając tego jednak ideologia. Z drugiej jednak strony trzeba podkreślić, że dyscypliny wykładane w szkołach biznesu są nader techniczne, logiczne i szczegółowe, ale o niczym (about nothing) ${ }^{26}$. Wiadomo, że biznes odrzuca kwestie społecznych procesów jako zewnętrzność i uznaje je za nieistotne, ale to samo czynią akademicy i wówczas mamy do czynienia w naukach o zarządzaniu z badaniami nad zarządzaniem bogactwem czy dobrobytem (wealth) bez studiów nad jego tworzeniem - i wtedy jest właśnie nauka o zarządzaniu niczym. Prace tego typu są niczym innym niż pochwałą kapitalizmu (a shill). Ta bardzo sprytna ideologia jest oczywiście w interesie biznesu ${ }^{27}$.

Kolejne pytanie w toczonej dyskusji dotyczyło problematyki emancypacji w programach kształcenia studentów, w tym intelektualnych możliwości, które oferuje CMS. Stwierdzono, że to właśnie dzięki CMS rozważa się dziśs w szkołach biznesu kwestie różnorodności tożsamości, przywództwa jako narracji, dyskursu, wyjaśnia, że jesteśmy konstruowani społecznie. Uznano, że tego typu elementy kształcenia moga sprzyjać inicjatywom polegajacym na monitorowaniu biznesu i doprowadzić do swoistego społecznego wyzwolenia ${ }^{28}$, jednakże to, co jest najbardziej istotne jako efekt CMS, to zmiany instytucjonalne w biznesie: tworzenie się organizacji, które są oparte na lokalnych formach wymiany, podejmowanych kolektywnie decyzjach i kulturowym pluralizmie. Rola badaczy w tym względzie nie jest jednoznaczna: z jednej strony

\footnotetext{
${ }^{24}$ Ibidem, s. 277.

${ }^{25}$ Ibidem, s. 279.

26 Ibidem, s. 282.

27 Ibidem.

28 Ibidem, s. 283.
} 
powinni wspierać owe ruchy społeczne i zmiany instytucjonalne własna praca i udziałem w życiu publicznym, z drugiej - zbyt często uczeni wykorzystuja wydarzenia społeczne w celu budowania własnych karier i pisania tekstów, w których pojawiają się komunały, wyświechtane frazesy, klisze (clichés), i które deprecjonują znaczenie tych społecznych wydarzeń ${ }^{29}$. W każdym jednak razie uniwersytety powinny być miejscem, które zachęca do myślenia i do wyzwolenia się z wcześniejszych nieaktualnych już idei.

Następny temat dyskusji dotyczył obecności i statusu teorii ekonomicznych w szkołach biznesu. Uczeni wskazali na silne wpływy ekonomii neoklasycznej (rozumianej jako nurt krytyczny wobec ekonomii klasycznej i teorii Keynesa) na kształt treści programów nauczania w uczelniach w USA i Wielkiej Brytanii. Jakkolwiek wspomniany nurt ukazuje słabości gospodarki kapitalistycznej (również i te, które przeniknęły do świadomości społecznej: kryzys finansowy, fiasko kredytów typu subprime), to z punktu widzenia kapitalizmu - oraz szkół biznesu, które tę teorię akceptuja - ideologia ekonomii neoklasycznej generuje szereg efektów pod hasłem przyszłej akumulacji kapitalistycznej i traktowania pracy naukowej jako niezbędnej dla tej akumulacji działalności. W programach studiów nie ma żadnych treści, które pozwalałyby zrozumieć zmagania pomiędzy praca (rynkiem pracy) a kapitałem czy akumulacja kapitału. Prowadzone w szkołach biznesu badania sa odpowiedzią jedynie na pytania biznesu i sa to odpowiedzi, które nie wywołuja nowych pytań. W tym zatem sensie ideologia ekonomii neoklasycznej nie jest pusta i ma praktyczne konsekwencje: badawcze i biznesowe. Jest też i tak, że jeżeli w badaniach są treści intelektualnie użyteczne dla innych obszarów niż biznes, to są one bezwzględnie eliminowane, ponieważ uczeni ze szkół biznesu są zjednoczeni wokół zasady, że społeczeństwo kapitalistyczne jest zarówno możliwe, oczekiwane, jak i w jakimś sensie przeznaczone (doomed).

To, co może budzić irytację, to brak teoretycznego uzasadnienia takiego sposobu myślenia ${ }^{30}$. Tym samym w pracach społeczności szkół biznesu trudno byłoby znaleźć krytykę biznesu, a właśnie szczera (forthright) krytyka kapitału jest tym, co powinno być uprawiane, w tym np. badania nad społecznymi uwarunkowaniami dochodów. Programy szkół biznesu są niemoralne: nie istnieje - wbrew temu co się sądzi - przekaz neutralnej wiedzy bądź umiejętności, ponieważ są one zawsze zgodne ze wskazaniami systemu kapitalistycznego. Jedyną umiejętnościa, którą można i należy w tej sytuacji kształtować, jest umiejętność bycia krytycznym. Problem polega na tym, że nie można najpierw nauczać umiejętności biznesowych zgodnych z programem kształcenia, a potem zaproponować studentom krytyczny w nie wgląd - w dziewiątym bądź dziesiątym tygodniu zajęć. Zdaniem uczonych uczestniczących w dyskusji edukacja w uczelniach ekonomicznych ma zawsze wymiar polityczny ${ }^{31}$ : może być krytyczna albo może nie być krytyczna (nawet umiejętność liczenia - jak pisali Einstein i Oppenheimer - ma wymiar polityczny). Z pewnością błędny oraz niemoralny jest również pogląd, że można

\footnotetext{
29 Ibidem, s. 283.

30 Ibidem, s. 274-275.

31 Ibidem, s. 286.
} 
uczyć studentów krytycznego myślenia dopiero np. od trzeciego roku, ponieważ wcześniej nie sa na to gotowi. W konsekwencji studenci nigdy nie nabywają w uniwersytetach umiejętności bądź ochoty bycia krytycznym. Tak zwane czołowe szkoły biznesu już dawno doprowadziły do destrukcji, zdyskredytowały i ośmieszyły wszystkie te idee, które nie wykluczyły pytań o walkę klas - po to, aby w badaniach i procesie edukacji uniwersytety nie musiały zajmować się radykalnym feminizmem, krytyką rasizmu, nierówności społecznych. Za destrukcję krytyki systemu kapitalistycznego jest również odpowiedzialna bezwzględność wymogu cytowalności tekstów, promowanie wybranych tekstów, sposoby zatrudniania i promowania uczonych, porozumienia z korporacjami wydawnictw i środowiskami zawodowymi, monopolizacja programów studiów przez ekonomię głównego nurtu. Doszło zatem do epistemicznej przemocy, do sytuacji, w której „the business school curriculum is empty", co oznacza, że programy kształcenia nie zawierają niczego, co jest niezbędne do analizy biznesu i zarządzania jako faktycznie występujacych praktyk oraz do uprawiania refleksji nad tymi programami ${ }^{32}$.

W jaki zatem sposób należy postrzegać zgodną z wyzwaniami współczesności rolę uczelni ekonomicznych oraz rolę krytycznie nastawionego wobec tych wyzwań środowiska akademickiego? Zdaniem dyskutujacych badaczy poważnym schorzeniem naszego środowiska jest samozadowolenie i przekonanie o wyjątkowości, które jest wzmacniane przez klientów, czyli studentów. Nastawieni krytycznie nauczyciele nie są słuchani, nie ma już wymagających i bojowniczych studentów, ponieważ ich zainteresowanie dotyczy wyłącznie nabywania biznesowego rzemiosła i umiejętności (craft). Temu nastawieniu studentów towarzyszy postawa uczelni, które stają się swoistymi maszynami/mechanizmami: sa zorientowane na własnym procesie pracy, programach studiów, planach produkowania artykułów, marce, znaku firmowym, patentach. Uniwersytety ekonomiczne i szkoły biznesu znalazły się w momencie wyjątkowym: powinny być otwarte na szerokie formy debaty publicznej i wspierać swą teoretyczną wiedzą popularną krytykę kapitalizmu, poszukiwać takich możliwości wewnątrz i na zewnątrz akademickich instytucji ${ }^{33}$. Do takich właśnie działań zobowiązuje zgromadzone w ich murach bogactwo zasobów.

Należy stwierdzić, że bioracy udział w dyskusji uczeni tak krytycznie oceniający sposób funkcjonowania szkół biznesu i pełnioną przez nie rolę społeczną są z pewnością bardziej radykalni w swoich poglądach i proponowanej wizji uczelni od programu PRME. Wyrażane explicite przekonania lewicowe i krytyczno-emancypacyjne wobec uczelni ekonomicznych nie sa jednak z pewnością niezbieżne z postulatami PRME dotyczącymi tworzenia gospodarki inkluzywnej (Zasada 1 - Cel), kształtowania globalnej odpowiedzialności społecznej (Zasada 2 - Wartości), uprawiania krytycznie nastawionych badań naukowych (Zasada 4 - Badania) i przede wszystkim angażowania się uczonych w debatę publiczną dotyczącą wyzwań współczesności (Zasada 6 - Dialog).

\footnotetext{
32 Ibidem, s. 288.

${ }^{33}$ Ibidem, s. 293.
} 


\section{ZAKOŃCZENIE}

Można sądzić, że przedstawione w tekście i konfrontowane z postulatami PRME wypowiedzi środowiska akademickiego stanowia artykulację aktualnych kulturowych oczekiwań wobec roli pełnionej przez uczelnie ekonomiczne $\mathrm{w}$ dobie globalizacji, dominowania modelu gospodarki rynkowej, urynkowienia relacji społecznych, wzrostu znaczenia koncepcji społecznej odpowiedzialności biznesu oraz przemian świadomości społecznej, które polegają na dostrzeżeniu doniosłości i potrzeby obywatelskiego angażowania się wszystkich w sprawy publiczne. Przytoczone opinie eksponują także konieczność podejmowania wspólnej refleksji nad przyjmowanymi odnośnie do środowiska akademickiego rozwiązaniami instytucjonalnymi i stanowiącymi fundament tych rozstrzygnięć - założeniami aksjologicznymi.

Problematyka kulturowych wzorów i schematów myślenia funkcjonujących $\mathrm{w}$ danym czasie i $\mathrm{w}$ danej społeczności jest od dawna przedmiotem namysłu filozoficznego. W pracy Anny Pałubickiej ${ }^{34}$ odnaleźć można interesujące rozważania dotyczące doniosłości uprawiania myślenia refleksyjnego dla powstania, rozwoju i zachowania tożsamości kultury Zachodu. Zgodnie z idea dualizmu sposobów partycypacji (nastawień/ postaw) w kulturze europejskiej: teoretycznego i praktycznego (naturalnego) ${ }^{35}$, myślenie refleksyjne charakterystyczne dla postawy kontemplująco-teoretycznej (schemat kulturowy) znajduje się w opozycji wobec nastawienia praktycznego (wzór kulturowy), w ramach którego myśli się spontanicznie, przedmiotowo i realistycznie zarazem oraz działa zgodnie wyłącznie z zawartym we wzorze opisem. Realność istnienia wzoru kulturowego sprowadza się do jego obowiązywania i odwrotnie - obowiązywanie wzoru stanowi uprawomocnienie jego istnienia ${ }^{36}$. Natomiast nastawienie teoretyczno-kontemplacyjne pozwala spojrzeć na nasze wzory myślenia (i regulowane przez nie działania) z dystansu, i postrzegać je jako wspólnotowo zaistniałe społeczne bądź kulturowe konstrukty. Zdaniem Pałubickiej charakterystyczna dla dziejów kultury Zachodu nadrzędność usytuowania postawy refleksyjnej wobec nastawienia narzędziowego jest dziśs silnie kwestionowana, a przecież tylko świadomość konstruowania naszego myślenia i szukanie odpowiedzi na zasadnicze pytanie: ,jak mamy myśleć o naszym (wytworzonym) myśleniu?"37, sa w stanie zmieniać świat.

Sądzę, że przytoczona powyżej teoria opisująca i wyjaśniająca proces stopniowego podporządkowania nastawieniu praktycznemu (narzędziowemu, operacyjnemu) postawy teoretyczno-kontemplacyjnej, niegdyśs nadrzędnej w kulturze Zachodu - pozwala na dostrzeżenie i głębsze zrozumienie doniosłości inicjatywy PRME jako efektu wspólnotowej refleksji nad współczesną kondycją uniwersytetów ekonomicznych i szkół biznesu.

dr hab. Barbara Pogonowska

Profesor Uniwersytetu Ekonomicznego w Poznaniu

barbara.pogonowska@ue.poznan.pl

\footnotetext{
${ }^{34}$ A. Pałubicka, Gramatyka kultury europejskiej, Bydgoszcz 2013.

35 Ibidem, s. 11.

${ }^{36}$ Ibidem, s. 102.

${ }^{37}$ Ibidem, s. 103.
} 


\section{THE ROLE OF BUSINESS SCHOOLS IN THE CONTEXT OF THE DECLARATION OF THE PRINCIPLES FOR RESPONSIBLE MANAGEMENT EDUCATION}

\section{Summary}

The papers deals with the beliefs concerning in the role of universities of economics and business schools. The author expresses a hope that the Declaration of the Principles for Responsible Management Education is as result of an intellectual reflection on the condition of universities in the contemporary world dominated by the concept of productivity. 
